\title{
On Public Participation in Local Budget
}

\author{
Yang Dezhi \\ School of Public Finance and Management, \\ Yunnan University of Finance and Economics, Kunming, Yunnan, China \\ Email:715812804@qq.com
}

\begin{abstract}
-public participation in local budgets is the inevitable requirement of governance-based budget. The exploration of public participation budget has accumulated some experience, but also should strengthen the legal support, improve the public participation ability and effective response mechanism construction.
\end{abstract}

\section{Keywords-local budget; Public participation; Promoting}

\section{THE OVERVIEW OF PUBLIC PARTICIPATION IN LOCAL} BUDGETS

\section{A. The local budget}

Our country implements five level of government budget, Including the central government budget、 the Provinces (or the autonomous regions 、the municipalities directly under the central government) budget the City divided into districts (or the autonomous prefecture) budget、 the county (or the autonomous county, the city not divided into districts ) budget 、 the township(or the nationality township、 the town) budget I In principle, all levels of government budgets except the central government budget are local budgets. In view of the 2015 new amendments to the " budget law" provisions of article 45, the people's congress of the county (or the autonomous county, the city not divided into districts) and the townships (or the nationality townships、 the towns) should hold a meeting to review the draft budget in a variety of forms, the organization of the people's congress at the corresponding level, listen to the views of voters and the community. So The local budget in this paper refers to the county and township budgets.

\section{B. The public participation}

The extension of public participation is rich, not only refers to the public participation in political activities such as elections, but also involves public participation in public interests and public affairs management. Public participation in local budget is mainly reflected in the following aspects: first, the new "budget law" affirmed the fourteenth budget to " open to the public", to ensure that citizens have access to adequate information. Secondly, the new budget law stipulates that the people's congresses at the county and township levels should listen to the views of citizens in a variety of forms, providing a legal basis for public participation in local budgets. Finally, article 91 of the new budget law stipulates that the public has the right to report and file charges against acts violating the budget law.

\section{The public participation in local budgets}

Many regions in China have carried out participatory budget practice in full swing, and formed their own local budget participation methods. According to the different leaders of public participation in local budgets, it can be divided into the national people's congress led the local budget ${ }^{1}$, the local budget led by the party Committee and the government ${ }^{2}$ and the local budget led by the hearing Committee $^{3}$. From the different stages of public participation in local budgets, it can be divided into budget decision making, budget implementation and budget accountability. ${ }^{4}$ Budget decision-making participation refers to the social organizations directly involved in the budget decision-making discussion and consultation, and thus affect the local budget participation. Budget execution is typically the purchase of public services by the government. Since the Ministry of finance promulgated the "Interim measures for the administration of government procurement of services" in 2014, the purchase of public services has become one of the conventional means of management of local governments. Public goods supply participants ( the public ) around the budget allocation and utilization of funds and performance evaluation and other matters to communicate with the administrative department, at the same time through the introduction of full competition mechanism to promote the efficient use of budget funds. Budget accountability participation means that the public participation in the budget accountability, can independently drive the accountability process, to the specific administrative departments to apply for budget information disclosure. Or with the aid of budget accountability procedures ( such as budget hearings), the

1 Such as Minhang district, Zhejiang Pinghu city, etc. On the basis of the detailed disclosure of specific budget items by government departments, the standing Committee of the national people's congress shall organize the NPC deputies and the public to participate in the debate on matters relating to the people's livelihood.

2 Such as Foshan Nanhai district, Guangdong province, wenling city, Zhejiang province, etc. Wenling city by the party Committee government to organize the government, the national people's congress and the public through the " democratic talkfest" way to participate in budget review. Nanhai district is dominated by the financial sector budget hearing, the formation of the hearing report by the national people's congress for examination and approval.

${ }^{3}$ Such as sanya, Hainan. The establishment of the hearing Committee, by the municipal people's congress, the national people's congress financial Committee, the Chinese people's political consultative conference, finance, supervision, auditing and other departments of staff, experts and scholars and representatives of taxpayers. Project funding arrangements need to be considered by more than two thirds of the members agreed.

${ }^{4}$ Chen zhi. the rule of law approach to local budget participation [j ]. legal research. 2017.56 - 60. 
government's budget behavior questioned or asked to explain and explain.

\section{THE PROBLEMS IN PUBLIC PARTICIPATION IN LOCAL} BUDGET

\section{A. The lack of legal support}

Although the new "budget act" institutionally affirms public participation in local budgets, the provisions on public participation are too broad, and the procedures, conditions and corresponding legal consequences of participation are not covered. Although the normative documents on public participation in local budgets issued by various localities have obvious local characteristics, the protection of public participation needs to be strengthened.

\section{B. The insufficient capacity of the public to participate in local budgets}

Compared with the public participation in other public affairs, budget participation undoubtedly put forward higher requirements for the public, resulting in the public participation in the budget has the problem of insufficient ability to participate. This is manifested in the lack of public understanding of budget knowledge, lack of rational judgment, and even participation in local budgets due to their own ability to lead to a mere formality.

\section{There is no response mechanism for public participation in local budgets}

The effective response of local budgeting, implementation and monitoring departments to public participation is an important guarantee for promoting public participation in local budgets. According to the experience of public participation in major decision-making of local governments and the practice of participating in local budgets, question raised by the public, whether budget departments give explanations, whether public opinions are reflected in the budget and the corresponding explanation should be institutionalized.

\section{THE PROPOSALS TO PROMOTE PUBLIC PARTICIPATION IN}

\section{LOCAL BUDGETS}

\section{A. Strengthening legislative support}

On the one hand, the position of public participation in local budget should be promoted, and public participation should be regarded as the basic principle of budget. While detailing the specific rights of the public to participate in the public budget. In the exploration of public participation in local budget, although there are many forms of participation, but until the actual maturity, the conditions, procedures and methods of public participation should be raised to the level of laws or regulations, to provide legal protection for public participation in local budget. On the other hand, to further improve the budget information disclosure system, clear the content and time of budget disclosure, to ensure that the public can complete and timely access to budget information.

\section{B. Effective improvement of citizen participation capacity.}

The ability of the public to participate in the deliberation and administration of state affairs can only be continuously improved in practice. In addition to the public to strengthen their own learning, the government can also guide the public to understand the basic budget knowledge in peacetime, if necessary, before the budget to carry out the relevant training. In addition, during the budget process, the capacity of citizens to participate in local budgets could be enhanced through the formation of specialized teams, with the assistance of experts. $C$. The formation of effective public participation response mechanism

In order to improve the public participation in the local budget, we need to broaden the channels of citizen participation, to provide citizens with multi - level, convenient way of participation, but also can not do without the establishment of effective response mechanism of notarization participation. At this stage, the local budget mainly considers the formation of a multi-mode opinion adoption mechanism to fully understand public views and indeed respond to public interest demands and suggestions. When the conditions are ripe, we should also consider establishing a budget performance evaluation system to establish the public as the main body of budget performance evaluation, and evaluate whether the budget preparation and implementation is appropriate and reasonable.

\section{ACKNOWLEDGEMENTS}

Thank you for the invitation of the organizing Committee of the fifth international conference on public administration, and for the hard work of the graduate school of public administration of oriental university of Thailand, school of finance and public administration of Yunnan university of finance and economics and their staff.

\section{REFERENCES}

1] Wang yongjun. new budget law: a review of the perspective of good governance [ j ]. China's finance. 2014.

[2] Li Yazhou. county people's congress budget trial hearing analysis and source [ j ]. national people's congress research. 2017.

[3] Diao YueNan. combined with the new budget law of the national people's congress budget supervision system [ j ]. legal Expo. 2015.

[4] Deng daQi. Dai HangNing. good budget governance depends on citizen participation [ $\mathrm{j}$ ] . people's forum. 2017. 